\title{
Effect of Artificial Solar Radiation on the Die-Off of Pathogen Indicator Organisms in Urban Floods
}

\author{
I. M. Scoullos ${ }^{1,2}$ (D) C. M. Lopez Vazquez ${ }^{2}$ (D) J. van de Vossenberg ${ }^{2}$ (D) M. Hammond ${ }^{3}$ (D) D. Brdjanovic $^{1,2}$ (D)
}

Received: 2 July 2018 / Revised: 4 October 2018 / Accepted: 12 November 2018 / Published online: 27 November 2018

(C) The Author(s) 2018

\begin{abstract}
In the last decade, flooding has caused the death of over 60,000 people and affected over 900 million people globally. This is expected to increase as a result of climate change, increased populations and urbanisation. Floods can cause infections due to the release of water-borne pathogenic microorganisms from surcharged combined sewers and other sources of fecal contamination. This research contributes to a better understanding of how the occurrence of water-borne pathogens in contaminated shallow water bodies is affected by different environmental conditions. The inactivation of fecal indicator bacteria Escherichia coli was studied in an open stirred reactor, under controlled exposure to simulated sunlight, mimicking the effect of different latitudes and seasons, and different concentrations of total suspended solids (TSS) corresponding to different levels of dilution and runoff. While attachment of bacteria on the solid particles did not take place, the decay rate coefficient, $k\left(\mathrm{~d}^{-1}\right)$, was found to depend on light intensity, $I\left(\mathrm{~W} \mathrm{~m}^{-2}\right)$, and duration of exposure to sunlight, $T\left(\mathrm{~h} \mathrm{~d}^{-1}\right)$, in a linear way $\left(k=k_{\mathrm{D}}+0.03 \cdot I\right.$ and $k=k_{\mathrm{D}}+0.65 \cdot T$, respectively) and on the concentration of TSS ( $\left.\mathrm{mg} \mathrm{L}^{-1}\right)$, in an inversely proportional exponential way $\left(k=k_{\mathrm{D}}+14.57 \cdot \mathrm{e}^{-0.02 \cdot[T S S]}\right)$. The first-order inactivation rate coefficient in dark conditions, $k_{\mathrm{D}}=0.37$ $\mathrm{d}^{-1}$, represents the effect of stresses other than light. This study suggests that given the sunlight conditions during an urban flood, and the concentration of indicator organisms and TSS, the above equations can give an estimate of the fate of selected pathogens, allowing rapid implementation of appropriate measures to mitigate public health risks.
\end{abstract}

\section{Article Highlights}

- It was demonstrated under controlled conditions that the inactivation of fecal indicator bacteria $E$. coli is higher under higher solar irradiance, longer duration of daylight and low TSS concentrations.

- The results indicate that under high TSS concentrations the bacteria, even if not attached on particles, are protected from photo-inactivation for a period of a few days, as the decay rate decreases exponentially with an increase in TSS concentration.

Keywords Solar inactivation $\cdot$ Urban drainage $\cdot$ Urban floods $\cdot$ Waterborne diseases

\section{Introduction}

The spread of pathogenic microorganisms by contaminated flood waters is a serious global problem connected with the

Electronic supplementary material The online version of this article (https://doi.org/10.1007/s41742-018-0160-5) contains supplementary material, which is available to authorized users.

\footnotetext{
I. M. Scoullos

i.scoullos@un-ihe.org

1 Department of Biotechnology, Delft University of Technology, Van der Maasweg 9, 2629 HZ Delft, The Netherlands
} spread of diseases. In the last 10 years, global floods have caused the death, by physical injury, drowning or infection,

2 Department of Environmental Engineering and Water Technology, IHE Delft Institute for Water Education, P.O. Box 3015, 2601 DA Delft, The Netherlands

3 Environment and Natural Resources Global Practice, World Bank Group, Washington, DC, USA 
of around 63,000 people, almost 158,000 in the last 20 years and affected over 900 million people (EM-DAT 2014). The initial presence or absence of pathogens in flood waters does not provide a reliable direct indication of the risks to human health. The transport and inactivation of the pathogens appear to play a crucial role in defining public health risks since most of the outbreaks of diseases occur within different time intervals after flooding events (Du et al. 2010; Taylor et al. 2011; Alderman et al. 2012). Several studies have shown that after a flood event, water-borne pathogens from humans and animals are commonly present on the flooded surfaces (ten Veldhuis et al. 2010; Rui et al. 2018). For example, in the Bellamyplein water plaza in Rotterdam, Campylobacter was found in high concentrations in the flood water, posing significant health risks (Sales-Ortells and Medema 2015). Despite the obvious importance of the issue, most studies until now were based on case-specific events, making it very difficult to have a broader understanding of the mechanisms of transport and inactivation of pathogens. To obtain a more realistic account of the overall health risks, it is necessary to assess the critical factors influencing the viability of pathogenic microorganisms in the urban environment under different environmental conditions.

Sunlight has been recognised as one of the predominant factors leading to the inactivation of enteric microorganisms in surface waters (Davies-Colley et al. 1999). The sensitivity of microorganisms to electromagnetic radiation depends on the wavelength and on the species of organisms and is described by biological weighting functions (Silverman and Nelson 2016). Although bacteria have greatest sensitivity to short wavelengths of light (Reed 2004), the short wavelength light is faster attenuated in the water column having a smaller fraction of the incident radiation (Silverman and Nelson 2016). Therefore, the lethal effect of sunlight on bacteria is more important in wavelengths higher than $320 \mathrm{~nm}$ (Oppezzo 2012). These wavelengths can cause indirect (photo-chemical, particularly photo-oxidative) damage, when absorbed by photosensitiser macromolecules within microbial cells (endogenous, such as porphyrins, bilirubin or chlorophyll) or in the surrounding water (exogenous, such as dissolved organic matter or humic acids) (Maraccini et al. 2016).

Suspended matter in water allows the encasement (adsorption/absorption) of microorganisms, offering protection from environmental stressors, such as grazing, adverse hydrodynamic conditions and irradiance, by offering shading (refraction, reflection and/or scattering). It can also offer increased access to nutrients of the particles or enhance settling. The degree to which particle association can impact light inactivation of enteric microorganisms in surface waters apparently is not yet clear (Walters et al. 2014).

In this study, the effects on the die-off of pathogens under various light conditions and in the presence of different concentrations of suspended solids were examined in an open reactor using a common indicator organism and an artificial light source with a spectrum similar to solar light. The experimental setting allowed to simulate different solar light intensities and durations that can occur at different times of the year and at different places around the globe. These conditions can be applied to all kinds of shallow water bodies, including multifunctional urban flood retention and detention basins often used as sport facilities or playgrounds during dry weather. Contamination could originate from wastewater from surcharged combined sewers, pit latrines, cross connections, open defecation, animal litter, or municipal and livestock operations. The selection of the light intensity and duration parameters was based on the conditions at two different latitudes: the equator and $60^{\circ}$. The equator zone was selected because it gets the maximum light intensity at a stable daytime length of $12 \mathrm{~h}$ throughout the year. $60^{\circ} \mathrm{N}$ and $\mathrm{S}$ were selected because of the daylight duration of 6 and $18 \mathrm{~h}$, respectively, in winter and summer solstice in the North and the opposite in the South.

This study provides a simple mathematical description of how bacterial inactivation is affected by the light conditions and the suspended solid concentrations, which can be used to create and/or upgrade models proposed for describing and predicting the fate and dispersion of pathogens leading to public health risks (Yakirevich et al. 2013; Jonsson and Agerberg 2014). Such models can be used as a tool for adaptation to climate change policies and strategies related to forecasting and properly informing key stakeholders and the public on health risks and appropriate measures associated with flooding events.

\section{Materials and Methods}

\section{Experimental Reactor}

Batch experiments took place in an open cylindrical stirred reactor of $40 \mathrm{~cm}$ internal diameter and $80 \mathrm{~cm}$ height. For each batch, the reactor was filled with $75 \mathrm{~L}$ of demineralised water (up to around $60 \mathrm{~cm}$ ); suspended solids and indicator organisms were added, according to each experimental phase. Continuous stirring at 95 rpm (IKA ${ }^{\circledR}$ dual-speed overhead stirrer, Staufen, Germany) was used to avoid settling. For maintaining the temperature of the reactor adequately constant at around $25^{\circ} \mathrm{C}$ (fluctuating between 20 and $28{ }^{\circ} \mathrm{C}$ ) and to neutralise the heating effect of the lamp, the reactor was placed in a larger tank containing water as a buffer while a ventilator was also employed. Each batch experiment lasted around 1 week, depending on the die-off rate and until the microorganisms were not fully detected. 


\section{Indicator Organisms}

Escherichia coli ATCC 25922 was chosen as the faecal indicator bacterium of study, because it has been studied thoroughly and can be grown easily under laboratory conditions. Before each batch experiment, $E$. coli was incubated in 1.3\% w/v Oxoid CM0001 Nutrient Broth (Oxoid Ltd., Basingstoke, United Kingdom) solution in Erlenmeyer flasks for $24 \mathrm{~h}$ at $37{ }^{\circ} \mathrm{C}$. After incubation, the concentration of the inoculum was around $3 \cdot 10^{9} \mathrm{CFU} \mathrm{mL}^{-1}$. The inoculation took place in the reactor by adding $280 \mathrm{~mL}$ of inoculum in demineralised water to achieve an initial concentration of E. coli of around $10^{7} \mathrm{CFU} \mathrm{mL}^{-1}$. The initial concentration of each batch was measured by sampling $15 \mathrm{~min}$ after the inoculation to allow full mixing. The selection of the initial concentration of $10^{7} \mathrm{CFU} \mathrm{mL}^{-1}$ was based on the typical high concentrations of $E$. coli in raw municipal wastewater of around $10^{6} \mathrm{CFU} \mathrm{\textrm {mL } ^ { - 1 }}$

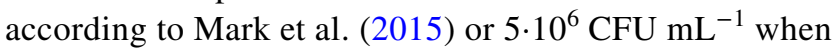
taking into account minor contributions of industrial wastewater (Henze and Comeau 2008).

The enumeration of $E$. coli in the samples was performed by counting the number of colony forming units (CFU) on Chromocult ${ }^{\circledR}$ Coliform Agar (CCA) (Merck $\mathrm{KGaA}$, Darmstadt, Germany) plates after $24 \mathrm{~h}$ of incubation at $37{ }^{\circ} \mathrm{C}$. Appropriate tenfold dilution steps in $0.1 \%$ peptone physiological salt solution were used. The plates were spread in triplicate.

\section{Suspended Solids}

To study the effects of different total suspended solids (TSS) concentrations, soil was used obtained from a previously flooded excavation site in Delft, The Netherlands. The soil was dried, ground and sieved. The particles selected for the experiment after sieving varied between sizes of 38 and $106 \mu \mathrm{m}$ (silt and fine sand). This fraction corresponds to frequently found particle sizes in urban environments, for example around $28 \%$ of the particle size distribution that was measured in a parking lot and at a residential basin (Selbig et al. 2016) and to around $50 \%$ of particles measured in asphalt road runoff (Charters et al. 2015). Subsequently, the solids were heated in a muffle furnace at $520{ }^{\circ} \mathrm{C}$ for $6 \mathrm{~h}$ to remove all organic compounds. The solids were added in the reactor in each batch experiment prior to the inoculation. The studied TSS concentrations varied from 0 to $200 \mathrm{mg} \mathrm{L}^{-1}$, because $200 \mathrm{mg} \mathrm{L}^{-1}$ is the reference value of US EPA for event mean concentration of TSS for urban runoff, while the similar ones according to NURP and to USGS and NPDES are lower, at 174 and $78.4 \mathrm{mg} \mathrm{L}^{-1}$, respectively (Acharya et al. 2010). The measurement of TSS was performed in triplicate with vacuum filtration using Whatman ${ }^{\circledR}$ Grade 1 (GE Healthcare, Little Chalfont, UK) filter papers ( $11 \mu \mathrm{m}$ pore size), so that solid particles with attached bacterial cells are retained while non-attached bacteria can pass through. Prior and after the filtration, the filter papers were dried at $105{ }^{\circ} \mathrm{C}$ for $2 \mathrm{~h}$ and the weight was determined.

\section{Light Source and Parameters}

Simulated sunlight was produced using an OSRAM HQIBT 400 W/D PRO metal halide lamp with built-in UV filter at around $320 \mathrm{~nm}$. Apart from a few peaks in the area of visible light (with the highest one at $540 \mathrm{~nm}$ ), the spectrum of these metal halide lamps is continuous (Calin and Parasca 2008). The light intensity was regulated by changing the distance of the light source from the water surface. The duration of light/darkness hours was set with a timer. The photon flux, in $\mu \mathrm{mol} \mathrm{m} \mathrm{m}^{-2} \mathrm{~s}^{-1}$, was measured with a LI-250A Light Meter equipped with an underwater quantum sensor (LI-COR ${ }^{\circledR}$ Biosciences, Inc., Lincoln, Nebraska, USA). This sensor has a uniform sensitivity in the range of wavelengths between 400 and $700 \mathrm{~nm}$; this was taken into account when calculating the lamp irradiance spectrum. The measurements were performed in duplicate, in different sides of the reactor. The light intensity, in $\mathrm{W} \mathrm{m}^{-2}$, was calculated with the Planck relation, taking into account the spectral power distribution of the lamp. More details on this are provided in the SI.

\section{Experimental Design}

\section{Assessment of Light Attenuation}

To address the phenomenon of light attenuation and calculate the light attenuation coefficient in the different conditions of the experiments, the photon flux was measured at different depths, with increments of $5 \mathrm{~cm}$, in the reactor filled with demineralised water inoculated with $E$. coli and with the addition of soil particles of different concentrations $\left(0,25,50,100,150\right.$ and $\left.200 \mathrm{mg} \mathrm{TSS} \mathrm{L}^{-1}\right)$.

\section{Effect of light intensity, duration of exposure to light and different concentrations of TSS on the viability of indicator organisms}

The effects of different light intensities (190 and $320 \mathrm{~W} \mathrm{~m}^{-2}$, for $12 \mathrm{~h} \mathrm{day}^{-1}$, without any solids added), periods of exposure to light $\left(0,6,12,18\right.$ and $24 \mathrm{~h} \mathrm{day}^{-1}$, under $320 \mathrm{~W} \mathrm{~m}^{-2}$, without addition of any solids) and different concentrations of TSS $\left(0,25,50,100,150\right.$ and $200 \mathrm{mg} \mathrm{L}^{-1}$, for continuous exposure to light of $320 \mathrm{~W} \mathrm{~m}^{-2}$ for $24 \mathrm{~h} \mathrm{day}^{-1}$ ) on the dieoff of the indicator organisms in demineralised water were studied. The viability of the organisms was also studied in dark conditions as a control. 


\section{Comparison of results by testing the inactivation of indicator organisms in artificial floodwater}

The inactivation of $E$. coli was studied in artificial floodwater. Domestic wastewater was used to mimic flood water. It was diluted ten times with demineralised water to simulate dilution by storm water runoff. The wastewater was collected from the influent stream of Harnaschpolder wastewater treatment plant, Den Hoorn, The Netherlands, after the first screening filters. Before dilution, the wastewater had a concentration of $29.6 \mathrm{mg}^{\mathrm{TSS} \mathrm{L}} \mathrm{L}^{-1}$ and $8.5 \cdot 10^{4} \mathrm{E}$. coli CFU mL ${ }^{-1}$. To study separately the effect of the wastewater's suspended solids, the experiment was performed by removing the wastewater's TSS with filtration using Whatman ${ }^{\circledR}$ GF/C (GE Healthcare, Little Chalfont, UK) filters $(1.2 \mu \mathrm{m}$ pore size) and replacing the TSS with $150 \mathrm{mg} \mathrm{L}^{-1}$ of the treated soil particles, as described before. E. coli was added in the reactor prior to the experiment to achieve an initial

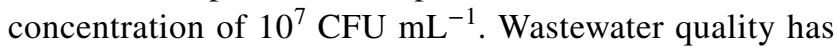
a high variability and the dilution factor from storm water increases the uncertainty even more. Therefore, the scope of this paper is limited in comparing demineralised water with diluted wastewater, both with the addition of soil particles. A comparison is made between the reported characteristics of flooding water and the synthetic flood water used in this research (see Table S1).

\section{Sampling and physicochemical parameters of study}

Samples of $20 \mathrm{~mL}$ were taken from the reactor at periodic intervals: (1) approximately, every $12 \mathrm{~h}$ when the light was on (2) at the beginning and end of each dark and light phase during the experiment of light duration, and (3) every $24 \mathrm{~h}$ when the decay was slow. The samples were taken from the top of the reactor with a $30 \mathrm{~mL}$ syringe. For the experiments involving suspended solids where it was important to assess stirring efficiency and sedimentation, samples were also taken from the middle and close to the bottom of the reactor by connecting a metallic tube to the syringe. The measurement of $\mathrm{pH}$ took place at the same intervals, with a handheld pH meter (WTW pH 323, WTW GmbH, Weilheim, Germany). Temperature and dissolved oxygen were measured every hour (fluctuating between 20 and $28{ }^{\circ} \mathrm{C}$ and between 6.5 and $8.5 \mathrm{mg} \mathrm{O}_{2} \mathrm{~L}^{-1}$, respectively, data not shown) with a handheld DO-meter (WTW Oxi 3310, WTW GmbH, Weilheim, Germany).

\section{Data Analysis}

Light attenuation due to different concentrations of suspended solids was addressed by measuring the vertical distribution of light in air and water with different concentrations of solids. This was described using an exponential function equivalent to Beer's law (Eq. 1), which states that the light intensity decreases exponentially as a function of depth:

$I_{(z)}=I_{(\text {surface })} \cdot e^{-\mu z}$

where $z$ is the depth $(\mathrm{m}), \mu$ is the light attenuation coefficient $\left(\mathrm{m}^{-1}\right), I_{(z)}$ is the light intensity $\left(\mathrm{W} \mathrm{m}^{-2}\right)$ at depth $z$ and $I_{\text {(surface) }}$ is the light intensity on the surface $(z=0 \mathrm{~m})$ (Kirk 1994; Morris et al. 1995).

In all the experiments where the inactivation of $E$. coli was addressed, the decay rates were calculated using the first-order exponential decay "Chick-Watson" model (Eq. 2):

$C(t)=C_{0} \cdot e^{-k t}$

where $t$ is the time (d), $C(t)$ is the measured concentration of

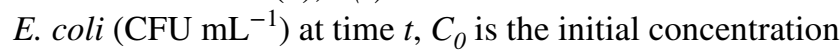
of $E$. coli measured in the reactor at time 0 and $k\left(\mathrm{~d}^{-1}\right)$ is the first-order decay rate constant. In all experiments, the inactivation was considered to start at time 0 with no lag period. Time 0 was considered as 15 min after inoculation to allow full mixing in the reactor before measuring $C_{0}$. For each batch experiment, the first-order decay rate was assumed to be constant.

Maraccini et al. (2016) and Davies-Colley et al. (2000) used the following linear model (Eq. 3) to express the total inactivation under light conditions as the sum of the photoinactivation plus the "dark" inactivation, due to stresses other than light, such as osmotic stress, predation and starvation:

$k=k_{\mathrm{D}}+k_{\mathrm{L}} \cdot I$

where $k_{\mathrm{D}}$ is the first-order dark inactivation rate constant $\left(\mathrm{d}^{-1}\right), k_{\mathrm{L}}$ is a pseudo-second-order photo-inactivation rate constant $\left(\mathrm{m}^{2} \mathrm{~W}^{-1} \mathrm{~d}^{-1}\right)$ and $I$ is the light intensity $\left(\mathrm{W} \mathrm{m}^{-2}\right)$. In the present study, a similar expression was also presented for the relation of $k$ to the duration of exposure to light $(T)$. Subsequently, $k_{\mathrm{D}}$ was calculated experimentally as the mean of the values corresponding to the intercept of linear regressions for zero intensity and exposure to light.

\section{Results and Discussion}

\section{Light Attenuation}

The vertical distribution of light intensity followed an exponential pattern, which corresponds to Beer's law, with values of $R^{2}>0.98$ for all the different TSS concentrations studied in the reactor (data is presented in Fig. S2). The light attenuation coefficient was proportional to the concentration of 
suspended solids and Eq. 4 was determined from a linear regression with $R^{2}=0.94$ :

$\mu=2.59+0.02 \cdot[$ TSS $]$

where $\mu$ is the light attenuation coefficient $\left(\mathrm{m}^{-1}\right)$ and [TSS] is the concentration of total suspended solids $\left(\mathrm{mg} \mathrm{L}^{-1}\right)$. The minimum theoretical value of $\mu$ corresponding to pure water is $2.59 \mathrm{~m}^{-1}$.

\section{Die-Off of E. coli Under Different Light Intensities}

The die-off of E. coli was studied in the reactor under exposure to light for $12 \mathrm{~h} \mathrm{day}^{-1}$ followed by $12 \mathrm{~h}$ in dark, without any solids added. The light intensities studied were 190 and $320 \mathrm{~W} \mathrm{~m}^{-2}$, with a control of $24 \mathrm{~h}$ in dark. The inactivation was described with exponential decay kinetics and the resulting decay rates are presented in Table 1 . The decay rate increases with an increase in light intensity and the data fit well $\left(R^{2}=0.99\right)$ to the linear Eq. 3 with $k_{\mathrm{D}}=0.19 \mathrm{~d}^{-1}$ and $k_{\mathrm{L}}=0.03 \mathrm{~m}^{2} \mathrm{~W}^{-1} \mathrm{~d}^{-1}$.

\section{Die-Off of E. coli Under Different Periods of Duration of Exposure to Light}

The die-off of $E$. coli was studied in the reactor, without any solids added, under exposure to light of $320 \mathrm{~W} \mathrm{~m}^{-2}$ for 0,6 , 12,18 and $24 \mathrm{~h} \mathrm{day}^{-1}$ followed by $24,18,12,6$ and $0 \mathrm{~h}$ in dark, respectively, per day. The inactivation was described with exponential decay kinetics for the overall curves and the resulting decay rates are presented in Table 1 . The decay rate increases with an increase in exposure time and the data fit well $\left(R^{2}=0.98\right)$ to the linear Eq. 5:

$k=k_{\mathrm{D}}+k_{\mathrm{L}}^{\prime} \cdot T$

where $k_{\mathrm{D}}=0.54 \mathrm{~d}^{-1}$ is the first-order dark inactivation rate constant corresponding to $0 \mathrm{~h}$ of exposure to light, $k_{\mathrm{L}}^{\prime}$ $=0.65 \mathrm{~h}^{-1}$ is a pseudo-second-order photo-inactivation rate constant, and $T$ is the duration of exposure to light per day $\left(\mathrm{h} \mathrm{d}^{-1}\right)$.

Table 1 Decay rates of $E$. coli in the reactor without addition of any solids for different light intensities (with $T=12 \mathrm{~h}$ of light per day) and for different periods of exposure to light (with $I=320 \mathrm{~W} \mathrm{~m}^{-2}$ )

\begin{tabular}{|c|c|c|c|}
\hline \multicolumn{2}{|c|}{ Different light intensities $(I)$} & \multicolumn{2}{|c|}{$\begin{array}{l}\text { Different periods of exposure to } \\
\text { light }(T)\end{array}$} \\
\hline$I\left(\mathrm{~W} \mathrm{~m}^{-2}\right)$ & $k\left(\mathrm{~d}^{-1}\right)\left(R^{2}\right)$ & $\overline{T(\mathrm{~h})}$ & $k\left(\mathrm{~d}^{-1}\right)\left(R^{2}\right)$ \\
\hline 0 (dark control) & $0.08(0.76)$ & 0 (dark control) & $0.04(0.47)$ \\
\hline 190 & $5.66(0.86)$ & 6 & $5.07(0.92)$ \\
\hline \multirow[t]{3}{*}{320} & $8.91(0.92)$ & 12 & $8.91(0.92)$ \\
\hline & & 18 & $10.96(0.95)$ \\
\hline & & 24 (light control) & $16.59(0.99)$ \\
\hline
\end{tabular}

\section{Determination of $\boldsymbol{k}_{\mathrm{D}}$}

The inactivation rate coefficient in dark conditions, $k_{\mathrm{D}}$, represents the effect of inactivation due to stresses other than light, such as osmotic stress, predation and starvation. Its theoretical value was calculated as the average of the intercepts resulting from the previous two linear regressions, $k_{\mathrm{D}}=(0.19+0.54) / 2=0.37 \mathrm{~d}^{-1}$. Although experimentally it was measured at a lower value in the dark control experiments conducted in this research $\left(0.08 \mathrm{~d}^{-1}\right.$ and $0.04 \mathrm{~d}^{-1}$, respectively), the calculated value is broadly consistent with the average values of dark inactivation rates for $E$. coli, of $0.55 \mathrm{~d}^{-1}$ (ranging from 0.34 to $0.79 \mathrm{~d}^{-1}$ ) in cold season and $0.79 \mathrm{~d}^{-1}$ (from 0.60 to $1.10 \mathrm{~d}^{-1}$ ) in warm season reported by Maïga et al. (2009), with those of 0.48 and $0.55 \mathrm{~d}^{-1}$ at average temperature of $20^{\circ} \mathrm{C}$ reported by Craggs et al. (2004), 0.41 and $0.55 \mathrm{~d}^{-1}$ calculated for waste stabilisation pond and raw sewage in fresh river water, respectively, by Sinton et al. (2002) and with $0.50 \mathrm{~d}^{-1}$ at around $24^{\circ} \mathrm{C}, \mathrm{pH} 8.0$ and $7.5 \mathrm{mg}$ $\mathrm{L}^{-1}$ dissolved oxygen in environmental water reported by Gutiérrez-Cacciabue et al. (2016).

\section{Die-Off of E. coli Under Different Concentrations of TSS}

To assess the role of suspended solids in the inactivation of indicator organisms, a series of batch experiments took place using different concentrations of TSS. The results of this experimental phase can be seen in Fig. 1.

Compared to the experiment in absence of suspended solids $\left(k=16.59 \mathrm{~d}^{-1}\right)$ it is clear from Fig. 1 that the decay rate decreased with increasing TSS concentration. With absence of suspended solids the decay curve was $\log _{10}$-linear, which was not the case in the presence of particles. In fact, in presence of solids, especially over $25 \mathrm{mg} \mathrm{L}^{-1}$, there was a one-day slow phase, followed by more rapid inactivation in the next couple of days. For concentrations of 50 and $100 \mathrm{mg} \mathrm{TSS} \mathrm{L}^{-1}$ the decay curves were almost identical, with decay rates of 5.21 and 5.78 $\mathrm{d}^{-1}$, respectively, and with the levels of $E$. coli falling under $10^{1} \mathrm{CFU} \mathrm{mL} \mathrm{mL}^{-1}$ before the 4 th day of the experiment. The steepest parts of these curves had decay rates of $9.24 \mathrm{~d}^{-1}$ for $50 \mathrm{mg} \mathrm{TSS} \mathrm{L}{ }^{-1}$ and $8.10 \mathrm{~d}^{-1}$ for $100 \mathrm{mg}$ TSS $\mathrm{L}^{-1}$, which were comparable to the one without solids $\left(16.50 \mathrm{~d}^{-1}\right)$ and to that of $25 \mathrm{mg} \mathrm{TSS} \mathrm{L}^{-1}\left(11.03 \mathrm{~d}^{-1}\right)$. For solids' concentrations of 150 and $200 \mathrm{mg} \mathrm{L}^{-1}$ the rapid inactivation decay rates were lower $\left(4.46\right.$ and $3.05 \mathrm{~d}^{-1}$, respectively), followed by a plateau between day 3 and day 5 , before the concentration of indicator organisms started falling more rapidly again, reaching levels below $10^{1}$ $\mathrm{CFU} \mathrm{mL}{ }^{-1}$. The E. coli bacteria in the experiment came from a pure culture and the experiment was performed in separate batches for 150 and $200 \mathrm{mg} \mathrm{TSS} \mathrm{L}^{-1}$, with 
Fig. 1 Concentration, $\log _{10}$ inactivation and decay rate $(k)$ of $E$. coli under exposure to artificial sunlight $\left(320 \mathrm{~W} \mathrm{~m}^{-2}\right.$, $24 \mathrm{~h} \mathrm{day}^{-1}$ ) with TSS $0,25,50$, 100,150 and $200 \mathrm{mg} \mathrm{L}^{-1}$, compared to dark control (no light and no solids). These curves correspond to the samples taken at the top of the reactor prior to filtration

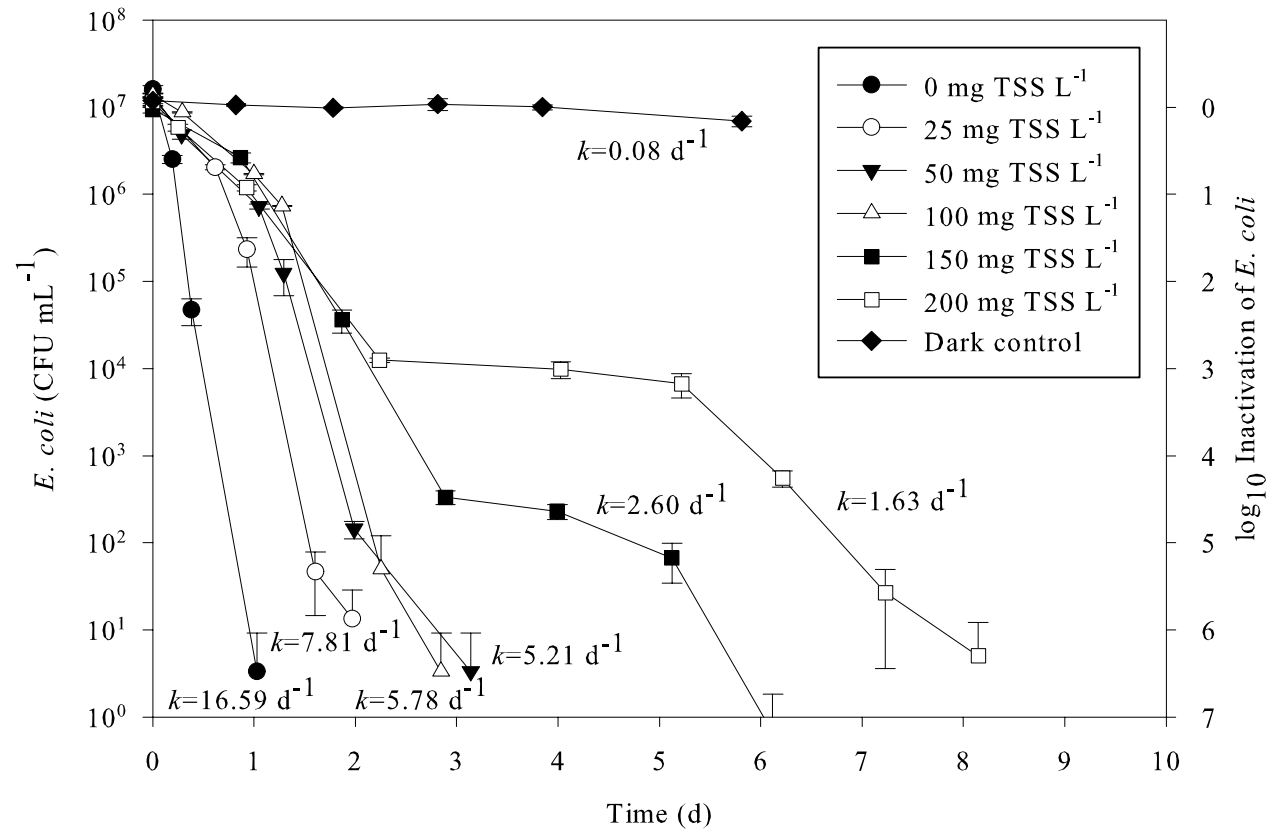



Fig. 2 The effect of TSS concentration $\left(\mathrm{mg} \mathrm{L}^{-1}\right.$, lower horizontal axis) and of light attenuation coefficient $\mu\left(\mathrm{m}^{-1}\right.$, upper horizontal axis) on decay rate $k\left(\mathrm{~d}^{-1}\right)$ of $E$. coli in the reactor under continuous exposure to artificial sunlight $\left(320 \mathrm{~W} \mathrm{~m}^{-2}\right)$. The coefficient $\mu$ was calculated based on Eq. 4

sampling in triplicate; therefore, the observed plateau was obtained in a reproducible manner. Brouwer et al. (2017) also observed such a deviation from the simple exponential decay and modelled that with biphasic decay dynamics (fast decay followed by a phase of slow decay) attributed to population heterogeneity, hardening off, viable-but-notculturable states and/or density effects. This raised the question of whether the bacteria were eventually attached to the TSS particles. This was examined in the experiments that follow.
The decay rates were calculated assuming the traditional model of monophasic decay for the overall period of the experiment, including the lag phase and the plateau, where it exists. The correlation between TSS concentration and overall decay rate $(k)$ can be seen in Fig. 2.

The decay rate $k\left(\mathrm{~d}^{-1}\right)$ decreases with an increase in the concentration of TSS $\left(\mathrm{mg} \mathrm{L}^{-1}\right)$ in an exponential way $\left(R^{2}=0.87\right)$ as described by the Eq. 6 :

$k=k_{\mathrm{D}}+14.77 \cdot \mathrm{e}^{-0.02 \cdot[\text { TSS] }}$

It can be assumed that for very high TSS concentrations light cannot penetrate in the water, so decay rate is similar to that of dark conditions; therefore, the $k_{\mathrm{D}}=0.37 \mathrm{~d}^{-1}$ parameter, as calculated previously, has been added to the exponential decay model.

The combination of this with the results of the first experiment leads to the formulation of an exponential relation (Eq. 7) between the decay rate $k\left(\mathrm{~d}^{-1}\right)$ and the light attenuation coefficient $\mu\left(\mathrm{m}^{-1}\right)$ :

$k=k_{\mathrm{D}}+65.48 \cdot \mathrm{e}^{-0.65 \cdot \mu}$

for $\mu \geq 2.59 \mathrm{~m}^{-1}$, which is the minimum theoretical value corresponding to the light attenuation coefficient of water without any solids, as calculated previously. Again, the $k_{\mathrm{D}}$ parameter has been added because it is assumed that for very high values of $\mu$ the decay rate is similar to that of dark conditions. This relation can be very useful as an indirect method for predicting the decay rate of E. coli-like pathogens in waters by measuring the vertical distribution of light, without the need of measuring the concentration of suspended solids or turbidity. More research on relevant methodologies has been conducted by Nguyen et al. (2015), 
Silverman and Nelson (2016) and presented in a critical review paper by Nelson et al. (2018).

At this point, it is interesting to note that although the irradiance of the UVA band of wavelengths of this lamp accounts for $5.1 \%$ of the total irradiance, as measured from the relative spectral power distribution, biological weighting functions show that the inactivation effect of wavelengths higher than $400 \mathrm{~nm}$ on E. coli is negligible (Nelson et al. 2018). Therefore, as the lamp has a UV filter at $320 \mathrm{~nm}$, we can assume that the total inactivation caused by this lamp corresponds to the UVA part of the spectrum. The values of the average UVA irradiance transmitted through the water column for the different TSS concentrations studied are presented in Table 2.

\section{Attachment and Particle-Related Shielding}

The attachment of E. coli on the suspended particles and particle-related shielding was tested in a batch experiment in Erlenmeyer flasks in an orbital shaker $(150 \mathrm{rpm})$ with $200 \mathrm{mg} \mathrm{TSS} \mathrm{L}^{-1}$ of solids in $250 \mathrm{~mL}$ of demineralised water by filtering samples of $25 \mathrm{~mL}$ and enumerating the bacteria in the filtered and unfiltered samples, in triplicate, at time zero and throughout the duration of the experiment. The soil particles used in the experiment were all selected, using sieving, to be larger than $38 \mu \mathrm{m}$ and smaller than $106 \mu \mathrm{m}$. The bacteria that could have been adhered or attached to particles were retained together with the particles on the filter paper of $11 \mu \mathrm{m}$. A t test for paired samples was performed to determine whether the concentrations of $E$. coli before and after filtration are likely to have come from distributions with equal population means. The value of t-statistic (0.93) was lower than the critical value (2.45), so the null hypothesis (that the mean difference in concentration between filtered

Table 2 Decay rates of E. coli in the reactor with demineralised water (DW) and artificial flood water (FW), at different concentrations of TSS

\begin{tabular}{lcllrl}
\hline $\begin{array}{l}\text { [TSS] }(\mathrm{mg} \\
\left.\mathrm{L}^{-1}\right)\end{array}$ & $I\left(\mathrm{~W} \mathrm{~m}^{-2}\right)$ & $I_{\mathrm{UVA}}\left(\mathrm{W} \mathrm{m}^{-2}\right)$ & $\mu\left(\mathrm{m}^{-1}\right)$ & $k\left(\mathrm{~d}^{-1}\right)$ & $k\left(\mathrm{~h}^{-1}\right)$ \\
\hline $0(\mathrm{DW})$ & 156.8 & 8.0 & 2.2 & 16.59 & 0.69 \\
$25(\mathrm{DW})$ & 125.3 & 6.4 & 3.3 & 7.81 & 0.33 \\
$50(\mathrm{DW})$ & 85.4 & 4.4 & 3.6 & 5.21 & 0.22 \\
$100(\mathrm{DW})$ & 65.7 & 3.4 & 4.9 & 5.78 & 0.24 \\
$150(\mathrm{DW})$ & 57.4 & 2.9 & 4.9 & 2.60 & 0.11 \\
$200(\mathrm{DW})$ & 37.3 & 1.9 & 6.4 & 1.63 & 0.07 \\
$150(\mathrm{WW})$ & 53.0 & 2.7 & 6.5 & 4.40 & 0.18 \\
\hline
\end{tabular}

The average total irradiance, $I$, transmitted through the water column (calculated from Eq. S2), as well as the average UVA irradiance (320-400 nm) transmitted through the water column, $I_{\mathrm{UVA}}=5.1 \% \cdot I$, and the light attenuation coefficient, $\mu$ (measured values), are also presented and unfiltered samples was zero) was accepted. Therefore, it is concluded with $95 \%$ confidence that the amount of indicator organisms associated with the suspended solids was not significant.

In addition to that, samples were taken from three different depths in the reactor: close to the surface $(2 \mathrm{~cm})$, middle $(30 \mathrm{~cm})$ and close to the bottom $(58 \mathrm{~cm})$. The concentration of suspended solids was found to be higher near the bottom of the reactor than at the middle and at the top of it because of sedimentation, with some fluctuations over time. The stirring speed was not increased, to avoid the creation of a vortex that would affect the water surface and the uniform distribution of light in the reactor. This inevitably caused the formation of a vertical TSS concentration gradient. Even so, E. coli was found to be uniformly distributed at different depths in the reactor (data not shown). This was observed both before and after filtration of the samples, supporting the finding that significant attachment did not occur for any of the TSS concentrations studied.

The absence of irreversible adsorption may be attributed to short incubation time with clean particles, stirring velocity, grain characteristics (size, size uniformity and surface roughness), solution chemistry (zeta potential, ionic strength), geochemical heterogeneity and lipopolysaccharide composition in the bacterial outer membrane (Foppen and Schijven 2006). According to Cantwell and Hofmann (2008), particle association affects the kinetics of inactivation by shielding the bacteria from exposure to light only when the number of particle-associated bacteria is significantly higher than the number of free-floating bacteria. The results indicate that also free-floating bacteria could be protected for some time due to shading under high concentrations of TSS and this is a conclusion of practical importance when strategies are conducted and measures are taken for appropriate protection of population in cases of floods.

\section{Comparison of Results by Testing the Inactivation of Indicator Organisms in Simulated Floodwater}

The decay rate of $E$. coli bacteria in the reactor filled with artificial floodwater containing $150 \mathrm{mg} \mathrm{TSS} \mathrm{L}^{-1}$ of treated solids and an initial $E$. coli concentration of 1.4. $10^{7} \mathrm{CFU} \mathrm{mL}^{-1}$, under continuous exposure to light of $320 \mathrm{~W} \mathrm{~m}^{-2}$, was $k_{\mathrm{FW}}=4.40 \mathrm{~d}^{-1}$. The predicted value of the decay rate at $150 \mathrm{mg} \mathrm{TSS} \mathrm{L}^{-1}$ for the same light conditions, according to Eq. 6, would have been $k_{\mathrm{DW}}=1.52$ $\mathrm{d}^{-1}$. Part of this difference between the predicted and the measured value may be explained by the effect of factors other than light, related to the components of wastewater. Therefore, the experiment was repeated in dark conditions to identify the effect of dark inactivation. In dark conditions, the decay rate in artificial floodwater was $k_{\mathrm{D}, \mathrm{FW}}=1.07 \mathrm{~d}^{-1}$, which was higher than the one calculated 
in demineralised water $\left(k_{\mathrm{D}, \mathrm{DW}}=0.37 \mathrm{~d}^{-1}\right)$. This confirms that the wastewater, although diluted, had a negative effect on the survival of $E$. coli in dark conditions. The decay rate of inactivation solely due to light, by subtracting the effect of dark inactivation from the overall decay rate, was equal to $k_{\mathrm{L}, \mathrm{DW}}=k_{\mathrm{DW}}-k_{\mathrm{D}, \mathrm{DW}}=1.15 \mathrm{~d}^{-1}$ for demineralised water and $k_{\mathrm{L}, \mathrm{FW}}=k_{\mathrm{FW}}-k_{\mathrm{D}, \mathrm{FW}}=3.33 \mathrm{~d}^{-1}$ for floodwater. The results can be seen in Fig. 3. This means that the negative effect of light was stronger in the floodwater than in demineralised water.

The threshold concentration of E. coli according to the EU Bathing Water Directive for sufficient water quality of inland waters is $9 \mathrm{CFU} \mathrm{mL} \mathrm{m}^{-1}$, based on a 90 -percentile evaluation of the $\log _{10}$ normal probability density function of microbiological data acquired from the particular bathing water (Directive 2006/7/EC). The 2012 Recreational Water Quality Criteria by US EPA recommend a 90-percentile statistical threshold value of $3.2 \mathrm{CFU} \mathrm{mL}^{-1}$ for E. coli in fresh water for primary contact recreation, including swimming, bathing, water play by children and similar water activities where a high degree of bodily contact with the water, immersion and ingestion are likely (US EPA 2012). According to the previous results, for an initial concentration of $10^{7}$ CFU E. coli $\mathrm{mL}^{-1}$, in floodwater the EU threshold would be met in $4.2 \mathrm{~d}$ and the US threshold would be met in $4.5 \mathrm{~d}$ if dark inactivation is not taken into account. In demineralised water, the two thresholds will be met only after 12.1 and $13.0 \mathrm{~d}$, respectively.
Although this work provides a better understanding of the die-off of indicator organisms in shallow water bodies, like urban retention and detention basins, further research has to be undertaken employing a wider range of water-borne pathogens and environmental conditions to be able to predict inactivation of pathogens under natural conditions.

\section{Conclusions}

- The light attenuation coefficient obtained in this study, which is proportional to the concentration of suspended solids, is: $\mu=2.59+0.02 \cdot[T S S]$, where $\mu$ is the light attenuation coefficient $\left(\mathrm{m}^{-1}\right)$ and $[T S S]$ is the concentration of total suspended solids $\left(\mathrm{mg} \mathrm{L}^{-1}\right)$.

- The decay rate decreases exponentially with an increase in TSS concentration, which can be described in this case as $k=k_{\mathrm{D}}+14.77 \cdot \mathrm{e}^{-0.02 \cdot[T S S]}$, where $k$ is the decay rate in $\mathrm{d}^{-1}$ and [TSS] is the concentration of total suspended solids in $\mathrm{mg} \mathrm{L}^{-1}$.

- In general, it was demonstrated under laboratory and controlled conditions that inactivation of pathogen indicators E. coli is higher under higher solar irradiance, longer duration of daylight and low TSS concentrations.

- The results indicate that under high TSS concentrations the bacteria, even if not attached on particles, are protected from photo-inactivation for a period of a few days.

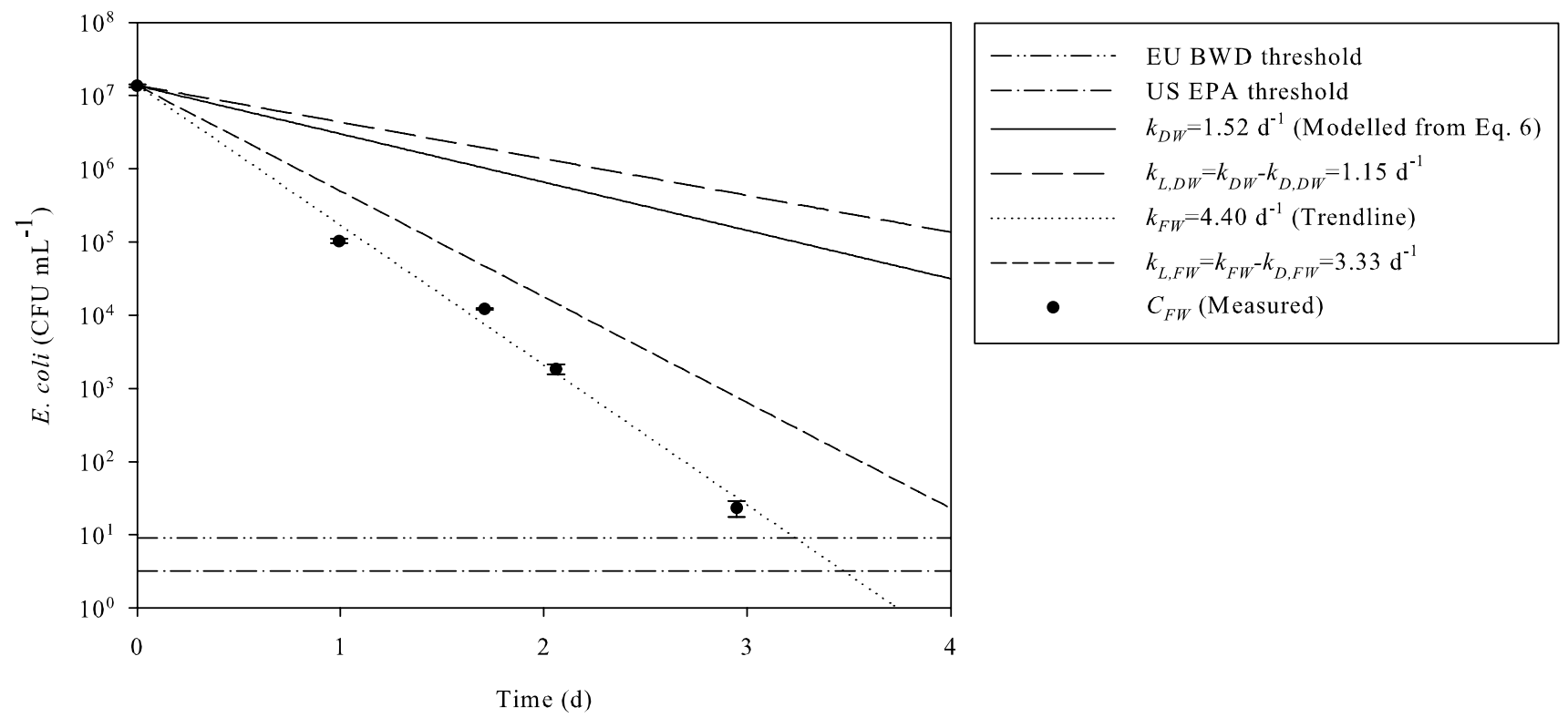

Fig. 3 The concentration of E. coli in artificial floodwater $\left(C_{\mathrm{FW}}\right.$, with decay rate $k_{\mathrm{FW}}$ ) measured in the reactor, compared to the theoretical curve for demineralised water with $k_{\mathrm{DW}}=1.52 \mathrm{~d}^{-1}$ calculated from Eq. 6 for $150 \mathrm{mg} \mathrm{TSS} \mathrm{L}{ }^{-1}$. The decay rates without the effect of dark inactivation for the two water qualities $\left(k_{\mathrm{L}, \mathrm{FW}}\right.$ and $k_{\mathrm{L}, \mathrm{DW}}$, respectively) were calculated by subtracting the dark inactivation rate from the overall decay rate. The curves were plotted using Eq. 2. The threshold concentrations of E. coli according to US EPA Recreational Water Quality Criteria and EU Bathing Water Directive are also presented 
- It is also noteworthy that the negative effect of light was stronger in the flood water experiments than in those with demineralised water.

- The results can be useful for numerical flood modelling and quantitative microbial risk assessment. Further research is needed, combining real environmental and operating conditions, like temperature and various water quality parameters, as well as with stronger pathogen indicators such as Cryptosporidium.

Acknowledgements We would like to gratefully acknowledge the Academy of Athens and the Alexander S. Onassis Public Benefit Foundation for their financial support of I. M. Scoullos. Thanks are due to the staff of the IHE Delft laboratories for their support and Dr. Eldon R. Rene for his helpful comments on the manuscript.

\section{Compliance with Ethical Standards}

Conflict of Interest On behalf of all authors, the corresponding author states that there is no conflict of interest.

Open Access This article is distributed under the terms of the Creative Commons Attribution 4.0 International License (http://creativeco mmons.org/licenses/by/4.0/), which permits unrestricted use, distribution, and reproduction in any medium, provided you give appropriate credit to the original author(s) and the source, provide a link to the Creative Commons license, and indicate if changes were made.

\section{References}

Acharya A, Piechota TC, Acharya K (2010) Characterization of first flush phenomenon in an urban stormwater runoff: a case study of Flamingo Tropicana watershed in Las Vegas valley. Am Soc Civ Eng ASCE. https://doi.org/10.1061/41114(371)347

Alderman K, Turner LR, Tong S (2012) Floods and human health: a systematic review. Environ Int 47:37-47

Brouwer AF, Eisenberg MC, Remais JV, Collender PA, Meza R, Eisenberg JNS (2017) Modeling biphasic environmental decay of pathogens and implications for risk analysis. Environ Sci Technol 51:2186-2196. https://doi.org/10.1021/acs.est.6b04030

Calin MA, Parasca SV (2008) Light sources for photodynamic inactivation of bacteria. Lasers Med Sci 24:453-460. https://doi. org/10.1007/s10103-008-0588-5

Cantwell RE, Hofmann R (2008) Inactivation of indigenous coliform bacteria in unfiltered surface water by ultraviolet light. Water Res 42:2729-2735. https://doi.org/10.1016/j.watres.2008.02.002

Charters FJ, Cochrane TA, O'Sullivan AD (2015) Particle size distribution variance in untreated urban runoff and its implication on treatment selection. Water Res 85:337-345. https://doi. org/10.1016/j.watres.2015.08.029

Craggs RJ, Zwart A, Nagels JW, Davies-Colley RJ (2004) Modelling sunlight disinfection in a high rate pond. Ecol Eng 22:113-122. https://doi.org/10.1016/j.ecoleng.2004.03.001

Davies-Colley RJ, Donnison AM, Speed DJ, Ross CM, Nagels JW (1999) Inactivation of faecal indicator micro-organisms in waste stabilisation ponds: interactions of environmental factors with sunlight. Water Res 33:1220-1230. https://doi.org/10.1016/S0043 $-1354(98) 00321-2$
Davies-Colley RJ, Donnison AM, Speed DJ (2000) Towards a mechanistic understanding of pond disinfection. Water Sci Technol 42(10-11):149-158

Directive 2006/7/EC of the European Parliament and of the Council of 15 February 2006 concerning the management of bathing water quality and repealing Directive 76/160/EEC. Official Journal of the European Union, 4.3.2006, L64/37. ELI: http://data.europa.eu/ eli/dir/2006/7/oj. Accessed 20 Jul 2017

Du W, FitzGerald GJ, Clark M, Hou X-Y (2010) Health impacts of floods. Prehosp Disaster Med 25:265-272

EM-DAT, The international disaster database (2014) Centre for research on the epidemiology of disasters. Available at http:// www.emdat.be/database. Accessed 20 Jun 2014

Foppen JWA, Schijven JF (2006) Evaluation of data from the literature on the transport and survival of Escherichia coli and thermotolerant coliforms in aquifers under saturated conditions. Water Res 40:401-426. https://doi.org/10.1016/j.watres.2005.11.018

Gutiérrez-Cacciabue D, Cid AG, Rajal VB (2016) How long can culturable bacteria and total DNA persist in environmental waters? The role of sunlight and solid particles. Sci Total Environ 539:494502. https://doi.org/10.1016/j.scitotenv.2015.07.138

Henze M, Comeau Y (2008) Wastewater Characterization. In: Henze M, van Loosdrecht M, Ekama G, Brdjanovic D (eds) Biological wastewater treatment: principles, modelling and design. IWA Publishing, London, p 35

Jonsson A, Agerberg S (2014) Modelling of E. coli transport in an oligotrophic river in northern Scandinavia. Ecol Model. https:// doi.org/10.1016/j.ecolmodel.2014.10.021

Kirk JTO (1994) Light and photosynthesis in aquatic ecosystems. Cambridge University Press, Cambridge

Maiga Y, Denyigba K, Wethe J, Ouattara AS (2009) Sunlight inactivation of Escherichia coli in waste stabilization microcosms in a sahelian region (Ouagadougou, Burkina Faso). J Photochem Photobiol B 94:113-119. https://doi.org/10.1016/j.jphotobiol .2008.10.008

Maraccini PA, Mattioli MCM, Sassoubre LM, Cao Y, Griffith JF, Ervin JS, Van De Werfhorst LC, Boehm AB (2016) Solar inactivation of enterococci and Escherichia coli in natural waters: effects of water absorbance and depth. Environ Sci Technol 50:5068-5076. https://doi.org/10.1021/acs.est.6b00505

Mark O, Jørgensen C, Hammond M, Khan D, Tjener R, Erichsen A, Helwigh B (2015) A new methodology for modelling of health risk from urban flooding exemplified by cholera—case Dhaka, Bangladesh. J Flood Risk Manag 11:S28-S42. https://doi. org/10.1111/jfr3.12182

Morris DP, Zagarese H, Williamson CE, Balseiro EG, Hargreaves BR, Modenutti B et al (1995) The attenuation of solar UV radiation in lakes and the role of dissolved organic carbon. Limnol Oceanogr 40(8):1381-1391

Nelson KL, Boehm AB, Davies-Colley RJ, Dodd MC, Kohn T, Linden KG, Liu Y, Maraccini PA, McNeill K, Mitch WA, Nguyen TH, Parker KM, Rodriguez RA, Sassoubre LM, Silverman AI, Wigginton KR, Zepp RG (2018) Sunlight-mediated inactivation of health-relevant microorganisms in water: a review of mechanisms and modeling approaches. Environ Sci Process Impacts 20:10891122. https://doi.org/10.1039/C8EM00047F

Nguyen MT, Jasper JT, Boehm AB, Nelson KL (2015) Sunlight inactivation of fecal indicator bacteria in open-water unit process treatment wetlands: modeling endogenous and exogenous inactivation rates. Water Res 83:282-292. https://doi.org/10.1016/j. watres.2015.06.043

Oppezzo OJ (2012) Contribution of UVB radiation to bacterial inactivation by natural sunlight. J Photochem Photobiol B 115:58-62. https://doi.org/10.1016/j.jphotobiol.2012.06.011 
Reed RH (2004) The inactivation of microbes by sunlight: Solar disinfection as a water treatment process. Advances in applied microbiology. Academic Press, Cambridge, pp 333-365

Rui Y, Fu D, Do Minh H, Radhakrishnan M, Zevenbergen C, Pathirana A (2018) Urban surface water quality, flood water quality and human health impacts in Chinese cities. What do we know? Water 10:240. https://doi.org/10.3390/w10030240

Sales-Ortells H, Medema G (2015) Microbial health risks associated with exposure to stormwater in a water plaza. Water Res 74:34 46. https://doi.org/10.1016/j.watres.2015.01.044

Selbig WR, Fienen MN, Horwatich JA, Bannerman RT (2016) The effect of particle size distribution on the design of urban stormwater control measures. Water 8:17. https://doi.org/10.3390/w8010 017

Silverman AI, Nelson KL (2016) Modeling the endogenous sunlight inactivation rates of laboratory strain and wastewater $E$. coli and enterococci using biological weighting functions. Environ Sci Technol 50:12292-12301. https://doi.org/10.1021/acs.est.6b037 21

Sinton LW, Hall CH, Lynch PA, Davies-Colley RJ (2002) Sunlight inactivation of fecal indicator bacteria and bacteriophages from waste stabilization pond effluent in fresh and saline waters. Appl Environ Microbiol 68:1122-1131. https://doi.org/10.1128/ AEM.68.3.1122-1131.2002
Taylor J, Lai KM, Davies M, Clifton D, Ridley I, Biddulph P (2011) Flood management: prediction of microbial contamination in large-scale floods in urban environments. Environ Int 37:1019-1029

ten Veldhuis JAE, Clemens FHLR, Sterk G, Berends BR (2010) Microbial risks associated with exposure to pathogens in contaminated urban flood water. Water Res 44:2910-2918. https:// doi.org/10.1016/j.watres.2010.02.009

US EPA 2012 Recreational water quality criteria. Office of water, United States Environmental Protection Agency. 820-F-12058. Washington, D.C., USA. Available at: https://www.epa. gov/wqc/2012-recreational-water-quality-criteria-documents. Accessed 20 Jul 2017

Walters E, Schwarzwälder K, Rutschmann P, Müller E, Horn H (2014) Influence of resuspension on the fate of fecal indicator bacteria in large-scale flumes mimicking an oligotrophic river. Water Res 48:466-477. https://doi.org/10.1016/j.watres.2013.10.002

Yakirevich A, Pachepsky YA, Guber AK, Gish TJ, Shelton DR, Cho KH (2013) Modeling transport of Escherichia coli in a creek during and after artificial high-flow events: three-year study and analysis. Water Res 47:2676-2688. https://doi.org/10.1016/j.watre s.2013.02.011 